\title{
The specificity of interactions between proteins and sulfated polysaccharides
}

\author{
BARBARA MULLOY \\ Laboratory for Molecular Structure, National Institute for Biological Standards and Control \\ South Mimms, Potter's Bar, Hertfordshire, EN6 3QG, UK \\ Manuscript received on May 11, 2005; accepted for publication on May 13, 2005; \\ presented by PAULO A. S. MOURÃO
}

\begin{abstract}
Sulfated polysaccharides are capable of binding with proteins at several levels of specificity. As highly acidic macromolecules, they can bind non-specifically to any basic patch on a protein surface at low ionic strength, and such interactions are not likely to be physiologically significant. On the other hand, several systems have been identified in which very specific substructures of sulfated polysaccharides confer high affinity for particular proteins; the best-known example of this is the pentasaccharide in heparin with high affinity for antithrombin, but other examples may be taken from the study of marine invertebrates: the importance of the fine structure of dermatan sulfate (DS) to its interaction with heparin cofactor II (HCII), and the involvement of sea urchin egg-jelly fucans in species specific fertilization. A third, intermediate, kind of specific interaction is described for the cell-surface glycosaminoglycan heparan sulfate (HS), in which patterns of sulfate substitution can show differential affinities for cytokines, growth factors, and morphogens at cell surfaces and in the intracellular matrix. This complex interplay of proteins and glycans is capable of influencing the diffusion of such proteins through tissue, as well as modulating cellular responses to them.
\end{abstract}

Key words: sulfated polysaccharides, fucans, dermatan sulfate, heparan sulfate, heparin, protein structure, growth factors, development.

\section{INTRODUCTION: SULFATED POLYSACCHARIDES AS POLYELECTROLYTES: NON-SPECIFIC INTERACTIONS}

Sulfated polysaccharides are found throughout the animal kingdom (Dietrich et al. 1989, Medeiros et al. 2000) and in some plants. They have diverse functions in their tissues of origin, and have more or less complex and often heterogeneous structures. They are not easy subjects for structural determination. Their large, acidic sulfate substituents dominate the physical characteristics of the isolated and purified compounds, and can equally dominate the

E-mail: bmulloy@nibsc.ac.uk effects of such preparations in biological systems. It is inevitable that these most acidic of biological macromolecules will be attracted to, and affect the activity of, any basic protein. There is no doubt that such interactions can lead to potent but non-specific biological activities, leading to skepticism of claims that important physiological processes may depend on subtle and specific distinctions between structures found in sulfated polysaccharides (Jones et al. 2004). There is, however, an increasing body of evidence that differences in patterns of sulfation along a polysaccharide are involved in recognition events, often outside the cell, and often involving 
change with time; fertilization, development, differentiation, inflammation, coagulation.

\section{INTERACTIONS WITH STRONG SPECIFICITY}

\section{HEPARIN AND ANTITHROMBIN}

The GAG heparin has been the most commercially and therapeutically important sulfated polysaccharide. For the first 30 years of its clinical use, not much was known about its structure except that it was composed of glucosamine and uronic acid, with heavy sulfate substitution (Petitou et al. 2003). Heparin has very much higher specific activity as an anticoagulant than other sulfated polysaccharides, due to its ability to potentiate the plasma serine protease inhibitor antithrombin. Efforts to purify heparin, in trying to achieve the highest possible sulfate content, in fact reduced its potency.

At about the same time, methods for structural determination of carbohydrates were under rapid development. The main repeating structure of heparin was established as a disaccharide of alternating $\mathrm{N}$ - and 6-O-sulfated $\alpha$-D-glucosamine and 2-Osulfated $\alpha$-L-iduronic acid (Perlin et al. 1971), with a minor proportion of $N$-acetyl glucosamine and $\beta$ D-glucuronic acid. (Figs. 1A, 1B) Determination of the structural motif in heparin with high affinity for antithrombin came, after years of painstaking work, from groups in France, Sweden, Italy and the USA (Petitou et al. 2003). This pentasaccharide sequence (Fig. 1C) is unusual, and is not found in every heparin molecule. Features essential to its affinity with antithrombin are indicated in the figure; the most striking of these is the 3-O-sulfated glucosamine (also $N$-sulfated and 6-O-sulfated) at the center of the oligosaccharide. The structure illustrated was confirmed by synthesis; the synthetic pentasaccharide has a high anticoagulant activity (Choay et al. 1983), and a version of this compound is now in use as an antithrombotic agent. Eventually the crystal structure of antithrombin with a heparin-like synthetic pentasaccharide bound to it was solved, and interactions mapped in great detail (Jin et al. 1997) (Fig. 2).
The high specificity of this interaction was unexpected. However, as a paradigm for heparin's other biological activities, the antithrombin system has not been successful; only in a few cases have unusual sequences been found with narrow preferences for their protein ligands. For example a 3,6$O$-sulfated, $\mathrm{N}$-unsubstituted glucosamine is characteristic of the receptor sequence for herpes simplex virus type 1 glycoprotein D (Liu et al. 2002, Shukla et al. 1999). In an interesting development, a 3$O$-sulfated heparan sulfate motif has recently been found in the pineal gland, predominantly during daylight hours (Kuberan et al. 2004).

Other examples of specific interactions between proteins and sulfated polysaccharide structures have however come from studies of marine organisms, always a rich source of unusual and interesting structures.

\section{DERMATAN SULFATES AND HEPARIN COFACTOR II}

Another mammalian glycosaminoglycan, dermatan sulfate (DS), has mild anticoagulant activity through its potentiation of heparin cofactor II (HCII), which, like antithrombin, is a plasma serine protease inhibitor. Mammalian dermatan sulfate has the structure shown in Fig. 3a, a disaccharide consisting of alternating 4-O-sulfated galactosamine and (for the most part) unsulfated iduronate residues. The DS sequence with high affinity for HCII, however, is sulfated not only at the 4- position of GalNAc, but in addition at the 2-position of IdoA (Maimone and Tollefsen 1990) (Fig. 3b). This sequence has a level of substitution twice that of the predominant repeat unit. Heparin, with three sulfates per disaccharide, also activates HCII; this at first sight is an example of a non-specific system in which density of sulfate substitution determines binding.

A dermatan sulfate-like compound from the marine invertebrate species Ascidia nigra was isolated and found to have $O$-sulfation at GalNAc C6 and IdoA C2 (Fig. 3c) (Mourão et al. 1997, Pavão et al. 1995) This DS-like molecule is much more highly sulfated than mammalian DS, but is not ca- 


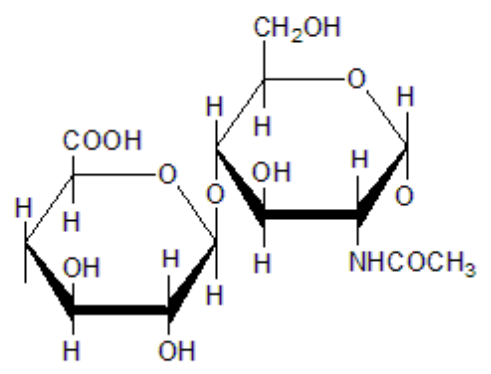

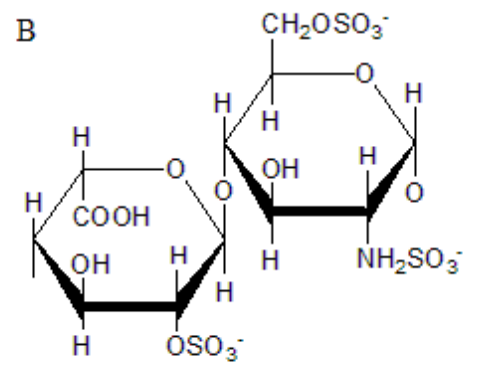

$\mathrm{C}$

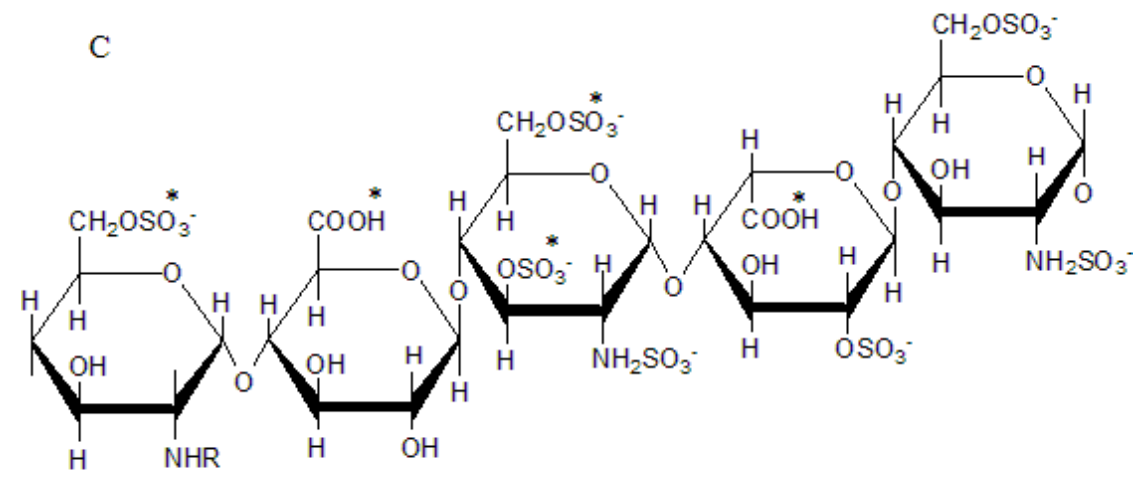
$\mathrm{R}=\mathrm{COCH}_{3}$ or $\mathrm{SO}_{3}^{-}$

Fig. 1 - Structures in heparin and heparan sulfate. A) The precursor polysaccharide for both heparin and heparan sulfate, [-4)- $\beta$-D-GlcA-( $1 \rightarrow 4)-\alpha$-D-GlcNAc-(1-], which is also the predominant structure in heparan sulfate. Post-polymerization, enzymes 1$)$ remove $N$-acetyl and replace with $N$-sulfate; 2) epimerize $\beta$-Dglucuronate residues at the reducing side of $N$-sulfate to $\alpha$-L-iduronate; 3) introduce 2- $O$-sulfate and 4) introduce 6- $O$-sulfate (Kusche-Gullberg and Kjellen 2003). The final result of all these transformations is shown in $\mathrm{B})$ the main repeating unit of heparin $[-4)-\alpha-\mathrm{L}-\mathrm{IdoA}\left(2 \mathrm{SO}_{3}^{-}\right)-(1 \rightarrow 4)-\alpha-\mathrm{D}-\mathrm{GlcNSO}_{3}^{-}\left(6 \mathrm{SO}_{3}^{-}\right)-(1-]$. Many intermediate structures arise from incomplete action of the post-polymerization enzymes. C) The pentasaccharide in heparin: [ 4)- $\alpha$-D-GlcNAc( $\left.6 \mathrm{SO}_{3}^{-}\right)-(1 \rightarrow 4)-\alpha$-D-GlcA- $(1 \rightarrow 4)-\alpha$-D-GlcNSO$-\left(3,6 \mathrm{diSO}_{3}^{-}\right)$$(1 \rightarrow 4)-\alpha-\mathrm{L}-\mathrm{IdoA}\left(2 \mathrm{SO}_{3}^{-}\right)-(1 \rightarrow 4)-\alpha-\mathrm{D}-\mathrm{GlcNSO}_{3}^{-}\left(6 \mathrm{SO}_{3}^{-}\right)-(1-]$ which is the minimal structure with high affinity for antithrombin, the serine protease in plasma which inhibits several coagulation enzymes. The substituents essential for this affinity are marked with an asterisk. 


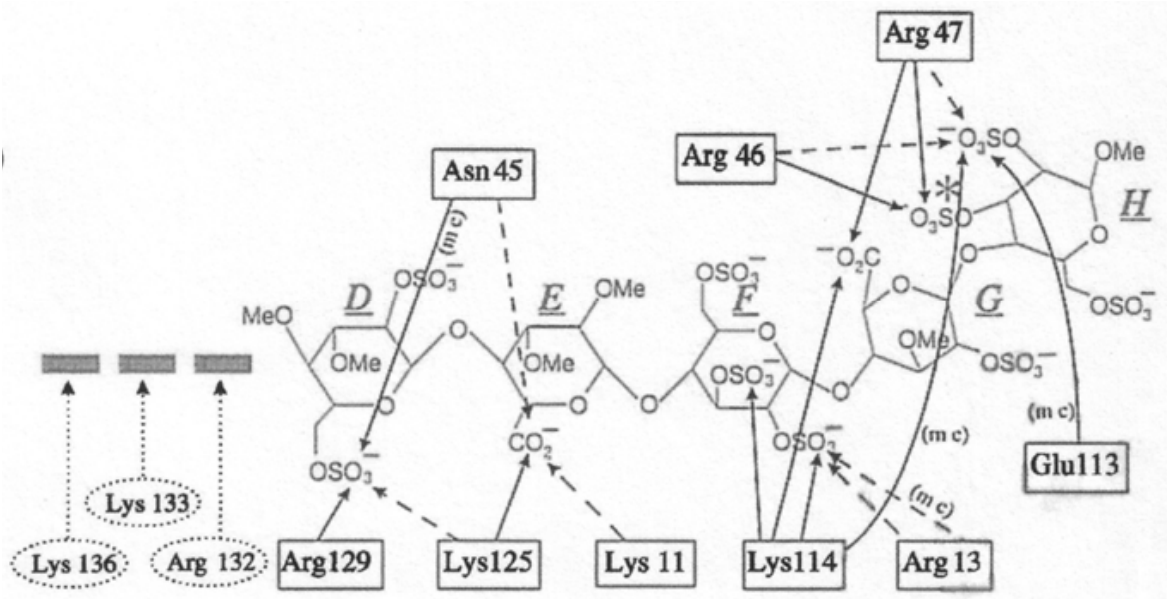

Fig. 2 - Details of protein-glycan contacts in the specific interaction between a heparin-like synthetic pentasaccharide and antithrombin; data from the crystal structure of the complex (Jin et al. 1997) (reproduced with permission). Likely hydrogen bonds are indicated by full lines, and possible bonds in interrupted lines. An extra sulfate is present in this non-natural structure, marked with an asterisk. A longer heparin chain, extended to the nonreducing side of the pentasaccharide shown, could interact with the three residues Arg 132, Lys 135 and Lys 136.

pable of activating HCII, and has no measurable anticoagulant activity. Dermatan sulfates from two other ascidian species, Halocynthia pyriformis and Styela plicata, are both composed predominantly of the structure in Fig. 2b, and as might be expected have anticoagulant activity higher than that of mammalian DS (Pavão et al. 1998).

It is therefore quite clear that, in the interaction between DS and HCII, it is the positions of the sulfate groups which are important, not merely the density of substitution.

\section{Sulfated FuCANS As Determinants of}

SPECIES SPECIFICITY IN SEA URCHINS

Sulfated fucans constitute an interesting group of polysaccharides; algal fucoidans are complex in structure, though a few studies have found regular repeating structures underlying their heterogeneity. These plant polysaccharides are abundant in coastal waters all over the world, and have been suggested as alternatives to heparin in that they share many biological activities (Berteau and Mulloy 2003).

Marine echinoderms, on the other hand, pro- duce fucans which are linear homopolymers of fucose, with a single linkage type, onto which a regular repeating oligosaccharide structure is imposed by varying substitution with sulfate groups (Fig. 4): one such has been isolated from sea cucumber wall (Ribeiro et al. 1994) and several others from the egg jelly of various sea urchin species (Mulloy et al. 1994b). It was noted that their structures are largely species specific (Fig. 3). Egg jelly fucans are involved in the acrosome reaction, a morphological change in the sperm necessary for fertilization of the egg. The fucan of each species was found to induce the acrosome reaction only in sperm from the same sea-urchin species; and so play a part in the species specificity of fertilization (Alves et al. 1997, Hirohashi et al. 2002). Some species have sub-populations with different fucan structures (Alves et al. 1998). Sea urchins are free-spawning organisms, and species sharing the same waters need to ensure species-specific fertilization of their eggs. This simple variation in sulfated fucan structure is not the sole determinant, but is a major contributor. The structures of fucans from a few other species 
A

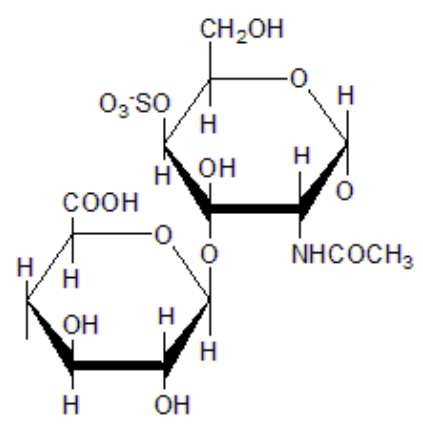

B
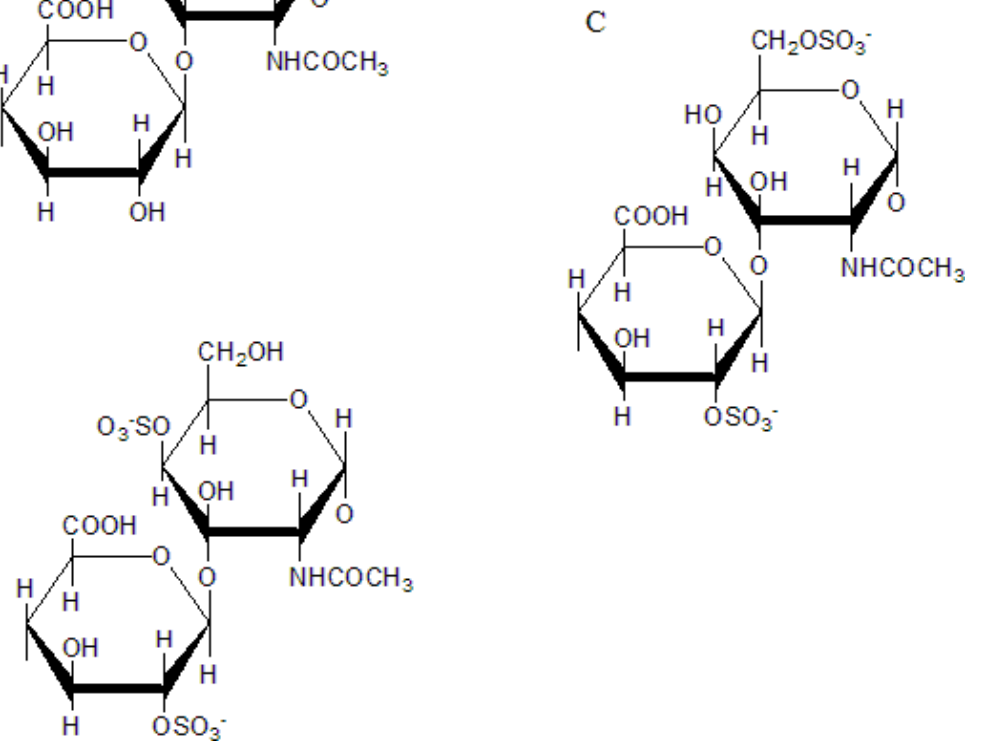

Fig. 3 - Structures of mammalian and invertebrate dermatan sulfates. A: The predominant disaccharide repeating unit of mammalian dermatan sulfate, [-4)- $\alpha$-L-IdoA- $(1 \rightarrow 3)-\beta$-D-GalNAc $\left(4 \mathrm{SO}_{3}^{-}\right)-(1-]$; $\mathrm{B}$ : the more highly sulfated disaccharide unit [-4)- $\alpha$-L-IdoA $\left(2 \mathrm{SO}_{3}^{-}\right)-(1 \rightarrow 3)-\beta$-D-GalNAc(4SO$\left.{ }_{3}^{-}\right)-(1-]$ which makes up the heparin cofactor II binding sequence in mammalian dermatan sulfate; $\mathrm{C}$ : the equally highly sulfated disaccharide unit [-4)- $\alpha$-L-IdoA $\left(2 \mathrm{SO}_{3}^{-}\right)-(1 \rightarrow 3)-\beta$-D-GalNAc$\left(6 \mathrm{SO}_{3}^{-}\right)-(1-]$ characteristic of ascidian dermatan sulfate, which does not confer any affinity for heparin cofactor II at all. The affinity of dermatan sulfate for heparin cofactor II depends not on sulfate content alone, but on the precise position of sulfate substitution.

of sea urchin have been determined (Vilela-Silva et al. 1999, 2002), but no doubt the oceans are full of many other as yet unknown structures. The anticoagulant activities and structures of algal and echinoderm fucans have been compared (Pereira et al. 1999).

\section{INTERACTIONS OF INTERMEDIATE SPECIFICITY: HEPARAN SULFATE WITH GROWTH FACTORS AND MORPHOGENS}

It is clear from the previous section that sulfated polysaccharides are capable of very specific, and physiologically important, interactions with pro- teins. The study of the sulfated glycan side-chains of proteoglycans, the glycosaminoglycans (of which both heparin and dermatan sulfate are members) has led recently to a more complex and subtle set of ideas about specificity, in which the differential affinities of proteins for various GAG sequences can affect the action of cytokines at the cell surface and can modulate their diffusion between cells. These properties are particularly relevant at times of change within tissues, for example during inflammatory episodes, in wound healing, and in embryonic development.

Heparan sulfate (HS) consists of the same 


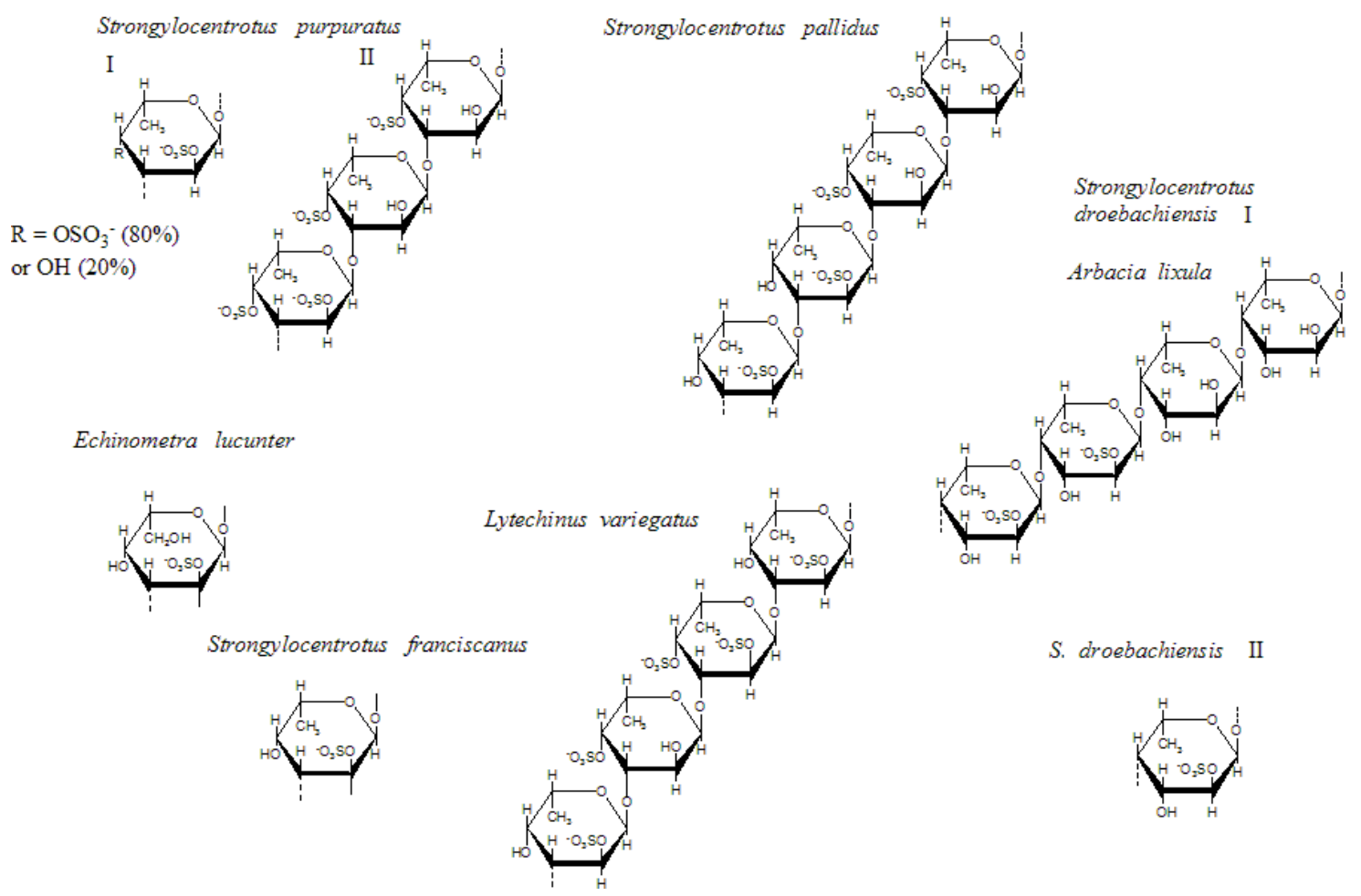

Fig. 4 - Structures of sea urchin egg-jelly fucans, important for species-specificity in fertilization. Unlike plant fucoidans, these linear polymers of $\alpha$-L-fucose have absolutely regular structures. Each has a single linkage type, with a characteristic pattern of sulfate substitution giving rise to a repeat unit of 1 to 4 monosaccharide residues. The species $S$. franciscanus has a 3- linked, 2-sulfated homopolymeric fucan, whereas $S$. pallidus and L. variegatus have 3-linked fucans in which patterns of sulfate substitution define a tetrasaccharide repeat. Species specificity of the fucans is not always simple: there are two populations of S. purpuratus with differing 3- linked fucan structures and two populations of S. droebachiensis with differing 4- linked fucans, one of which is identical with the fucan from the species A. lixula. The two species with identical egg-jelly fucans are not found in the same waters, so the potential problem of cross-fertilization does not arise.

structural elements as heparin (indeed heparin is now regarded as a highly sulfated mast cell heparan sulfate). HS is almost ubiquitous as the glycosaminoglycan component of such proteoglycans as syndecans and glypicans on the surfaces of mammalian cells, and perlecan in the extracellular matrix. The GlcA-GlcNAc disaccharide makes up most of the structure of HS, interrupted by $N$-sulfated, iduronate-containing sequences known as S-regions. It is through these heparin-like S-regions that HS interacts with proteins.

Conformational studies of heparin by NMR and molecular modeling have shown that the poly- saccharide chain has a relatively well-defined shape, regardless of its pattern of sulfate substitution (Mulloy et al. 1993, 1994a) (Fig. 5). The sulfate substituents occur in clusters spaced at intervals of about $17 \AA$ down either side of the polysaccharide chain, each cluster consisting of one $N$-sulfate, one 2- $O$-sulfate, and one 6- $O$-sulfate, from three successive residues.

In the study of heparan sulfate-protein interactions, the more readily available heparin has been extensively used as a model compound, as fully sulfated heparin can occupy heparan sulfate binding sites with no loss of affinity. The extra sul- 

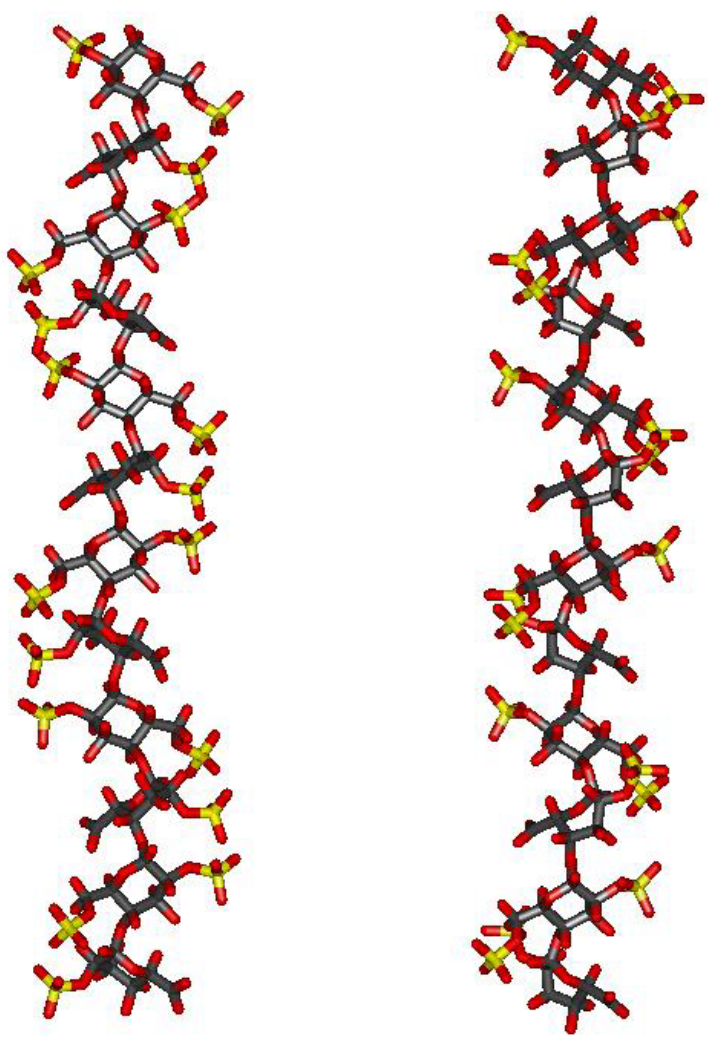

Fig. 5-The solution structure of heparin, as determined by NMR spectroscopy. The two models have iduronate residues in the ${ }^{1} \mathrm{C}_{4}$ and ${ }^{2} \mathrm{~S}_{0}$ conformations respectively. Sulfate substituents are arranged along the polysaccharide chain in groups of three, alternating on opposite sides of the molecule. Co-ordinates are from the PDB file $1 \mathrm{HPN}$. The stick representation is colored grey for carbon, red for oxygen, blue for nitrogen and yellow for sulfur.

fates do not interfere with binding. In the interaction between HS and a protein ligand, as long as the minimal specific motif of sulfate substitution in the HS S-region is present, different substitution patterns can be accommodated in the same binding site. This allows complex patterns of differential affinities between proteins with different specificities and heparan sulfate sequences (Ashikari-Hada et al. 2004). A further level of specificity may be added in those interactions, usually involving protein oligomers, where two heparan sulfate S-regions are required for optimum affinity, separated by a defined length of unsulfated, more flexible polysac- charide. This is the case for several chemokines such as platelet growth factor 4 (Stringer and Gallagher 1997), interleukin-8 (Lubineau et al. 2004) and MIP-1 $\alpha$ (Stringer et al. 2002, 2003).

\section{FIBROBLAST GROWTH FACTORS}

Fibroblast growth factors (FGFs) I and II are probably the best studied ligands of heparin after antithrombin. Cell-surface heparan sulfate forms part of the receptor complex for these growth factors, and these two FGFs have different requirements in terms of heparan sulfate fine structure (Pye et al. 2000). FGF-1 can act as an example of the class of proteins which has a preference for a specific pattern of sulfate substitution best defined not in terms of sequence but in terms of a spatial distribution of sulfate groups.

Fig. 6a shows a detail of the of the heparin/ FGF-1 complex crystal structure (DiGabriele et al. 1998). Two FGF-1 molecules bind to opposite faces of a heparin oligosaccharide. At first sight this appears to be a symmetrical system, but in fact it is not; as is clear from Fig. 6b, one copy of FGF-1 binds with a sulfate cluster and an $N$-sulfate from the next cluster (towards the non-reducing end), whereas the other binds with a sulfate cluster and a 6-O-sulfate from the next cluster (towards the reducing end). The requirements of the FGF-1 heparin binding site can therefore be satisfied in more than one way.

This observation may be useful in the interpretation of binding data obtained, not from heparin, but from a library of octasaccharides derived from HS and separated by affinity chromatography on immobilized FGF-1 (Jemth et al. 2002). One feature, consistently associated with high affinity by inspecting the sequences, is a trisaccharide motif (-IdoA2S-GlcNS6S-IdoA2S-) (Kreuger et al. 2001). However when the sequences are presented in a simplified three-dimensional format (Fig. 7), it becomes clear that the motif of one complete cluster and one sulfate from the next cluster is present in high affinity octasaccharides and absent in lower affinity octasaccharides of the same overall 


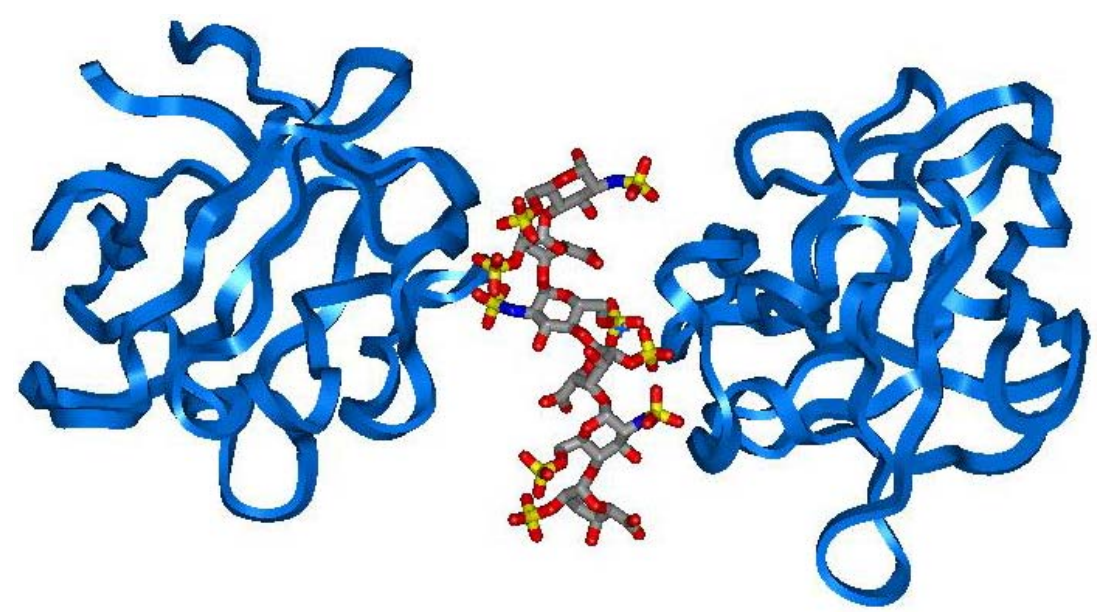

A

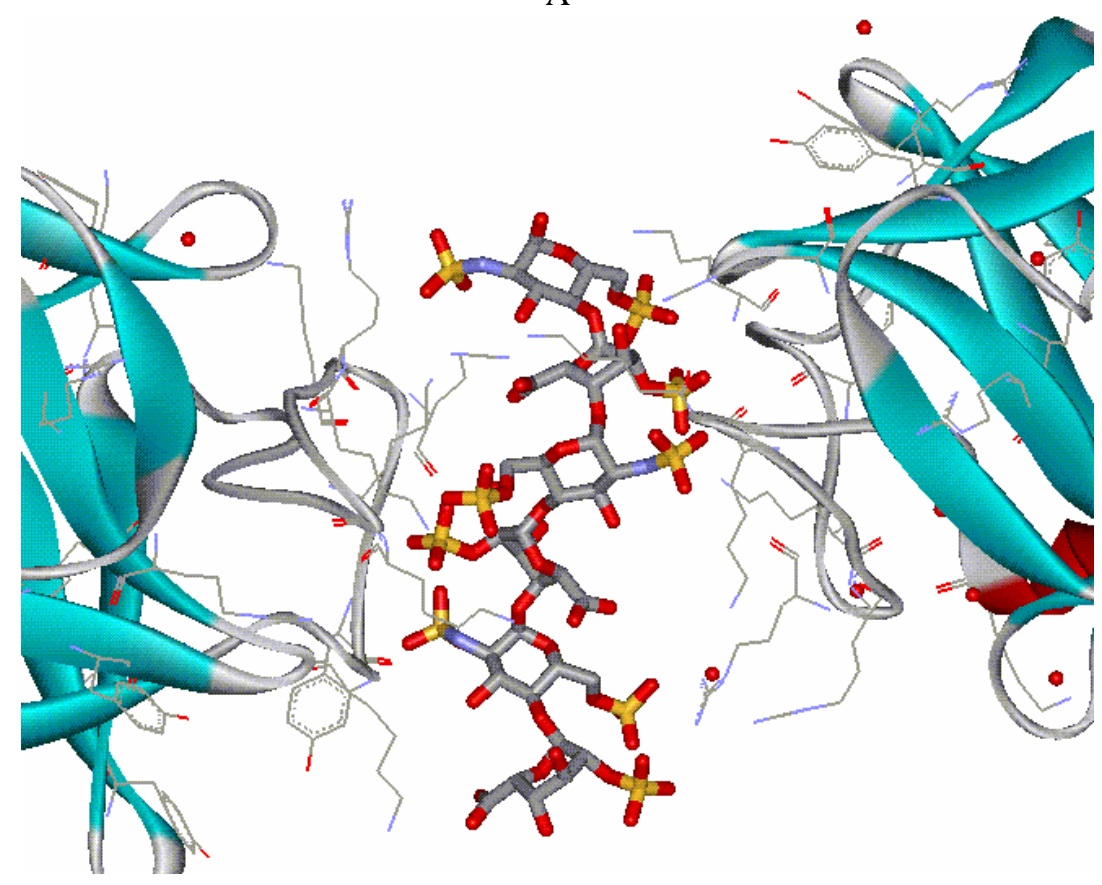

B

Fig. 6 - FGF-1 and a heparin oligosaccharide: A: crystal structure of the complex (from coordinates in the PDB file 1AXM). Two copies of the FGF-1 monomer are depicted in a blue ribbon representation, with the heparin as in Fig. 5; B: An expansion of the area around the heparin molecule, with amino acid sidechains shown as thin sticks. Each of the FGF-1 molecules makes close contacts with sulfates in one complete cluster of three (see Fig. 5) and one or two sulfates from a subsequent cluster. The whole structure is not in fact symmetrical, and the two FGF-1 molecules are interacting with different sequences, but recognition depends in this case more strongly on a particular pattern of sulfates in three dimensions than on the sequence which presents that pattern. 
level of sulfate substitution. Synthetic heparin-like oligosaccharides with sulfate substitution along one 'side' only of the molecule are, as would be predicted from this reasoning, capable of binding to FGF-1; more surprisingly, they can also enhance its mitogenic activity (Angulo et al. 2004).

There are more than 20 known members of the fibroblast growth factor (FGF) family, most of which are predicted to have a conserved heparinbinding site (Venkataraman et al. 1999). It has also been recognized that the individual isoform of the FGF receptor involved in the complex contributes to the specificity of interactions with heparan sulfate, as has been demonstrated using a library of heparan sulfate oligosaccharides (Guimond and Turnbull 1999) and using chemically modified heparins and heparin oligosaccharides (Lundin et al. 2000, Ostrovsky et al. 2002). Crystal structures have been determined for two FGF-FGFR-heparin ternary structures; FGF1-FGFR2-heparin decasaccharide (Pellegrini et al. 2000) and FGF2-FGFR1-heparin decasaccharide (Schlessinger et al. 2000). Despite similarities between the components of the complexes, the two structures show some striking differences, for example predicting different stoichiometries and models for receptor dimerization (Pellegrini 2001); it has been suggested that both types of complex may be involved in the formation of extended signaling complexes on the cell surface (Harmer et al. 2004). The numerous close heparinprotein contacts observed in the crystals have not allowed an unambiguous determination of minimal binding sequences. It has been pointed out that in addition to ionic interactions, shape complementarity influences specificity; a "kink" may be observed in the polysaccharide on binding to FGF (Raman et al. 2003).

\section{HeParan Sulfate In Development}

The example of the fibroblast growth factors demonstrates how the detailed three-dimensional structure of heparan sulfate allows for sequence variations which produce structural motifs capable of differential affinities with growth factors and with growth factor/receptor pairs. This property may be an important factor in the space and time specific shaping of morphogen gradients during embryonic development.

Investigations of the influence of HS fine structure on affinity for a given protein may be carried out in a variety of ways. Direct binding experiments involving the protein of interest and systematically modified heparins (Ostrovsky et al. 2002) or heparan sulfate oligosaccharide libraries (Ashikari-Hada et al. 2004) can often be informative but recently the rapid rise of genomics and genetic manipulation has provided interesting and sometimes surprising evidence concerning the importance of specific substitution patterns in glycosaminoglycans. The enzymes which convert polymeric, unsulfated precursors (such as heparosan, Fig. 1B) into the fully sulfated active sequences (such as those for heparin, Figs. 1A and 1C) have been especially informative (Kusche-Gullberg and Kjellen 2003, Nakato and Kimata 2002). The sulfotransferases in particular may exist in several isoforms which are specific with respect to the type of sequence preferred as substrate. Expression of these isoforms, for example of HS6ST (heparan sulfate 6- $O$-sulfotransferase) and HS2ST (heparan sulfate 2-O-sulfotransferase), takes place in developing tissues in defined areas and at defined times (Habuchi et al. 2004). This provides a mechanism by which specific affinities of HS sequences for different growth factors and morphogens can form the gradients which give rise to correct formation of the developing embryo; for example in the nervous system (Bulow and Hobert 2004), heart (Yue et al. 2004), limb buds (Berry et al. 2003, Nogami et al. 2004), and in cartilage (Kirn-Safran et al. 2004). In the kidney, absence of 2-O-sulfation leads to failure of kidney development: 2-O-desulfation impairs binding of heparin to glial cell line-derived neurotrophic factor (Rickard et al. 2003).

It is also increasingly recognized that chondroitin sulfate sequences may display similar properties, being involved in development, nerve regen- 

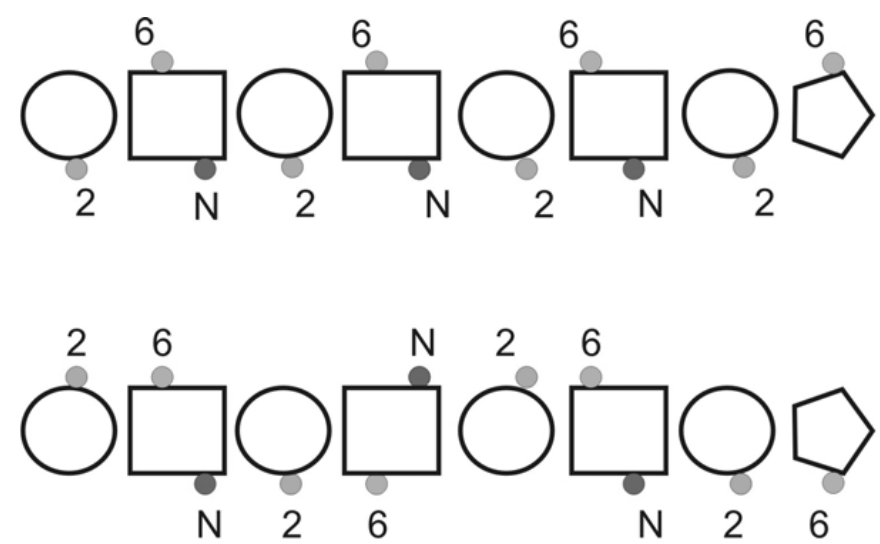

2 (N) 6

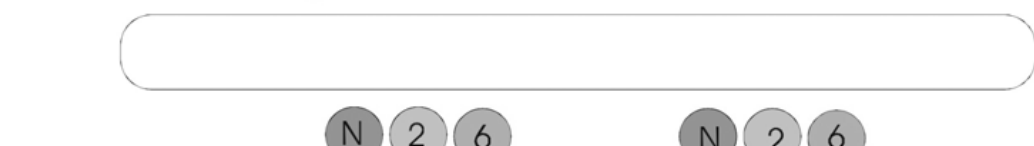

Maximum sulfation

(N) 6

N 26

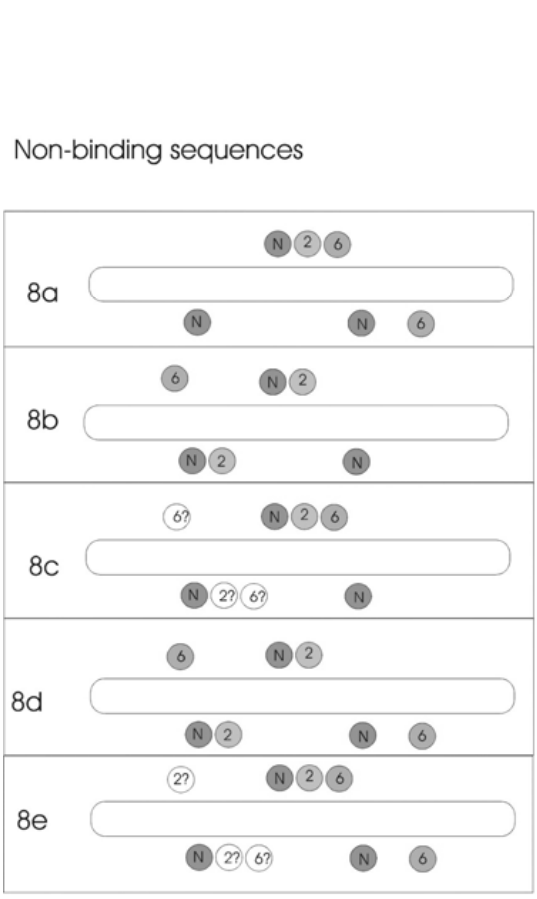

\section{Binding sequences}

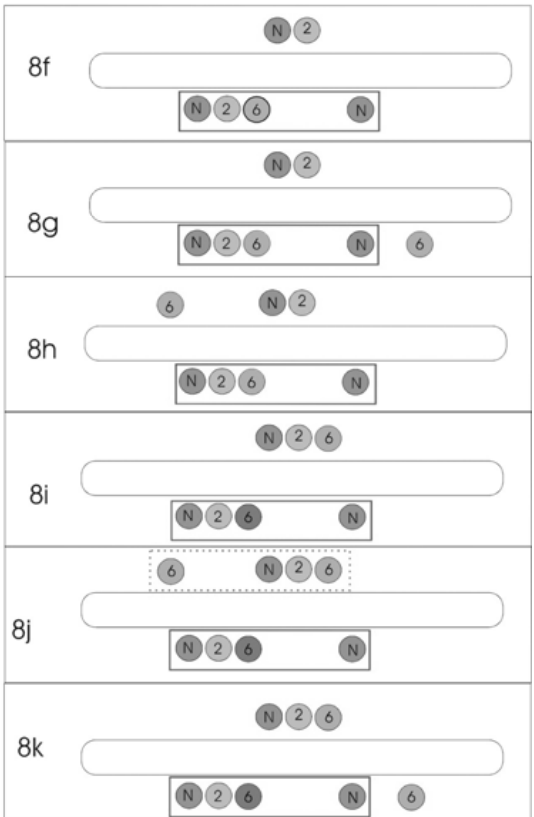

Fig. 7 - A) Heparin represented i) as a sequence of iduronate (circles) and glucosamine (squares) with sulfate substitution represented as small filled circles; ii) with alternate disaccharides inverted, to show the clusters of three sulfates on either side of the molecule (see Fig. 5) and iii) in the simplified version of ii) used in B) a library of heparan sulfate oligosaccharides with varying affinities for FGF-1 as estimated by affinity chromatography. The sequences on the right (8f-8k) all show some degree of affinity for immobilized FGF-1, and all contain the pattern of sulfates seen interacting with FGF-1 in the crystal structure (see Fig. 6). 
eration, and as pathogen receptors (Sugahara et al. 2003).

Of course, the properties of heparan sulfate in regulation of cell growth and division have a negative side, and the role of heparan sulfate and extracellular heparanase in the growth of tumors has recently been reviewed (Sanderson et al. 2004). On the positive side, it is possible to look forward to the development of novel therapeutic agents which will surely be developed on the basis of our rapidly increasing understanding of the structural basis of heparan sulfate-protein interactions (Coombe and Kett 2005).

\section{CONCLUSIONS}

Sulfation patterns alone can confer on a polysaccharide precise, physiologically important specificity in interactions with proteins. Subtle variations in patterns of sulfation of glycosaminoglycans can modulate relative affinities for information bearing extracellular proteins such as cytokines, growth factors and morphogens. This is the basis of their various functions in embryonic development and in tumor growth.

\section{RESUMO}

Os polissacarídeos sulfatados são capazes de se ligar às proteínas com diferentes níveis de especificidade. São macromoléculas altamente ácidas que podem se ligar de forma inespecífica a qualquer domínio básico da superfície de uma proteína em soluções com baixa força iônica, contudo tais interações não parecem ser fisiologicamente significativas. Por outro lado, foram identificados vários sistemas nos quais componentes estruturais muito específicos dos polissacarídeos sulfatados conferem alta afinidade para algumas proteínas. O exemplo mais conhecido é o pentassacarídeo da heparina com alta afinidade pela antitrombina. Outros exemplos podem ser observados no estudo de invertebrados marinhos, tais como a importância da estrutura fina do dermatam sulfato para sua interação com o cofator II da heparina e o envolvimento de fucanas sulfatadas encontradas no gel que envolve os óvulos dos ouriços-do-mar na espécie especificidade da fertilização. Um terceiro exemplo de interação específica é aquele descrito para o glicosaminoglicano heparam sulfato encontrado na superfície celular. Neste caso, o padrão de sulfatação pode determinar diferentes afinidades do carboidrato por citoquinas, fatores de crescimento e outras proteínas encontradas na superfície celular e na matriz extracelular. Estas interações complexas entre proteínas e carboidratos são capazes de influenciar a difusão das proteínas através dos tecidos, assim como modelar a resposta celular a estas moléculas.

Palavras-chave: polissacarídeos sulfatados, fucanas, dermatam sulfato, heparam sulfato, heparina, estrutura de proteína, fatores de crescimento, desenvolvimento.

\section{REFERENCES}

Alves AP, Mulloy B, Diniz JA And Mourão PA. 1997. Sulfated polysaccharides from the egg jelly layer are species-specific inducers of acrosomal reaction in sperms of sea urchins. J Biol Chem 272: 6965-6971.

Alves AP, Mulloy B, Moy GW, VAcquier VD AND MourÃo PA. 1998. Females of the sea urchin Strongylocentrotus purpuratus differ in the structures of their egg jelly sulfated fucans. Glycobiology 8 : 939-946.

Angulo J, Ojeda R, de Paz JL, Lucas R, Nieto PM, Lozano RM, REdondo-Horcajo M, GIMENEZ-GALlego G AND MARTIN-LOMAS M. 2004. The activation of fibroblast growth factors (FGFs) by glycosaminoglycans: Influence of the sulfation pattern on the biological activity of FGF-1. Chembiochem 5: 55-61.

ASHIKARI-Hada S, HabUCHI H, KaRIYA Y, ITOH N, Reddi AH AND Kimata K. 2004. Characterization of growth factor-binding structures in heparin/heparan sulfate using an octasaccharide library. J Biol Chem 279: 12346-12354.

Berry KL, Bulow HE, Hall DH and Hobert O. 2003. A C. elegans CLIC-like protein required for intracellular tube formation and maintenance. Science 302: 2134-2137.

Berteau O ANd Mulloy B. 2003. Sulfated fucans, fresh perspectives: structures, functions, and biological properties of sulfated fucans and an overview of enzymes active toward this class of polysaccharide. Glycobiology 13: 29-40. 
Bulow HE AND Hobert O. 2004. Differential sulfations and epimerization define heparan sulfate specificity in nervous system development. Neuron 41: 723-736.

Choay J, Petitou M, Lormeau JC, Sinay P, Casu B ANd GATti G. 1983. Structure-activity relationship in heparin: a synthetic pentasaccharide with high affinity for antithrombin III and eliciting high antifactor Xa activity. Biochem Biophys Res Commun 116: 492-499.

CoOmbe DR AND KeTt WC. 2005. Heparan sulfateprotein interactions: therapeutic potential through structure-function insights. Cell Mol Life Sci 62: 410-424.

Dietrich CP, NAder HB, De Paiva JF, Santos EA, Holme KR and Perlin AS. 1989. Heparin in molluscs: chemical, enzymatic degradation and ${ }^{13} \mathrm{C}$ and ${ }^{1} \mathrm{H}$ n.m.r. spectroscopical evidence for the maintenance of the structure through evolution. Int J Biol Macromol 11: 361-366.

Digabriele AD, Lax I, Chen DI, SVAhn CM, Jaye M, SCHLESSINGER J AND HENDRICKSON WA. 1998. Structure of a heparin-linked biologically active dimer of fibroblast growth factor. Nature 393 : 812-817.

Guimond SE ANd Turnbull JE. 1999. Fibroblast growth factor receptor signalling is dictated by specific heparan sulphate saccharides. Curr Biol 9: 1343-1346.

HabUChi H, HabUChi O AND Kimata K. 2004. Sulfation pattern in glycosaminoglycan: Does it have a code? Glycoconj J 21: 47-52.

Harmer Nu, Ilag Ll, Mulloy B, Pellegrini L, Robinson CV AND BLundell TL. 2004. Towards a resolution of the stoichiometry of the fibroblast growth factor (FGF)-FGF receptor-heparin complex. J Mol Biol 339: 821-834.

Hirohashi N, Vilela-Silva ACES, Mourão PAS AND VACQUIER VD. 2002. Structural requirements for species-specific induction of the sperm acrosome reaction by sea urchin egg sulfated fucan. Biochem Biophys Res Commun 298: 403-407.

Jemth P, Kreuger J, Kusche-Gullberg M, StuRiAle L, GimeneZ-Gallego G AND LindAhL U. 2002. Biosynthetic oligosaccharide libraries for identification of protein-binding heparan sulfate motifs. Exploring the structural diversity by screening for fibroblast growth factor (FGF)1 and FGF2 binding. J Biol Chem 277: 30567-30573.

Jin L, Abrahams JP, Skinner R, Petitou M, PIKE RN AND CARRELl RW. 1997. The anticoagulant activation of antithrombin by heparin. Proc Natl Acad Sci USA 94: 14683-14688.

Jones LS, Yazzie B And Middaugh CR. 2004. Polyanions and the Proteome. Mol Cell Proteomics 3: 746-769.

KIRN-SAFran CB, GOMES RR, BROWN AJ AND CARSON DD. 2004. Heparan sulfate proteoglycans: coordinators of multiple signaling pathways during chondrogenesis. Birth Defects Res C Embryo Today 72: 69-88.

Kreuger J, Salmivirta M, Sturiale L, GimenezGallego G AND Lindahl U. 2001. Sequence analysis of heparan sulfate epitopes with graded affinities for fibroblast growth factors 1 and 2. J Biol Chem 276: 30744-30752.

Kuberan B, LeCh M, BorJigin J AND RosenberG RD. 2004. Light-induced 3-O-sulfotransferase expression alters pineal heparan sulfate fine structure. A surprising link to circadian rhythm. J Biol Chem 279: 5053-5054.

Kusche-Gullberg M And KJellen L. 2003. Sulfotransferases in glycosaminoglycan biosynthesis. Curr Opin Struct Biol 13: 605-611.

LIU J ET AL. 2002. Characterization of a heparan sulfate octasaccharide that binds to herpes simplex virus type 1 glycoprotein D. J Biol Chem 277: 33456-33467.

Lubineau A, Lortat-Jacob H, Gavard O, SARRAZIN S AND BONNAFFE D. 2004. Synthesis of tailor-made glycoconjugate mimetics of heparan sulfate that bind IFN-gamma in the nanomolar range. Chemistry 10: 4265-4282.

Lundin L, Larsson H, Kreuger J, Kanda S, Lindahl U, SALMivirta M AND ClaEsSONWELSH L. 2000. Selectively desulfated heparin inhibits fibroblast growth factor-induced mitogenicity and angiogenesis. J Biol Chem 275: 24653-24660.

Maimone MM AND Tollefsen DM. 1990. Structure of A Dermatan Sulfate Hexasaccharide That Binds to Heparin Cofactor-Ii with High-Affinity. J Biol Chem 265: 18263-18271. 
Medeiros GF, Mendes A, Castro Ra, Bau EC, NADER HB AND DieTrich CP. 2000. Distribution of sulfated glycosaminoglycans in the animal kingdom: widespread occurrence of heparin-like compounds in invertebrates. Biochim Biophys Acta 1475: 287-294.

Mourão PA, PavÃo MS, Mulloy B And Wait R. 1997. Chondroitin ABC lyase digestion of an ascidian dermatan sulfate. Occurrence of unusual 6- $O$ sulfo - 2 - acetamido - 2 - deoxy - 3 - $O$ - (2 - $O$ - sulfoalpha - L - idopyranosyluronic acid) - beta - D - galactose units. Carbohydr Res 300: 315-321.

Mulloy B, Forster MJ, Jones C And Davies DB. 1993. N.m.r. and molecular-modelling studies of the solution conformation of heparin. Biochem J 293: 849-858.

Mulloy B, Forster MJ, Jones C, Drake AF, JoHnson EA AND DAVIES DB. 1994a. The effect of variation of substitution on the solution conformation of heparin: a spectroscopic and molecular modelling study. Carbohydr Res 255: 1-26.

Mulloy B, Ribeiro AC, Alves AP, Vieira RP AND Mourão PA. 1994b. Sulfated fucans from echinoderms have a regular tetrasaccharide repeating unit defined by specific patterns of sulfation at the 0-2 and 0-4 positions. J Biol Chem 269: 22113-22123.

NAKATO H AND KimatA K. 2002. Heparan sulfate fine structure and specificity of proteoglycan functions. Biochim Biophys Acta 1573: 312-318.

Nogami K, Suzuki H, Habuchi H, Ishiguro N, IWATA H AND KimATA K. 2004. Distinctive expression patterns of heparan sulfate $O$-sulfotransferases and regional differences in heparan sulfate structure in chick limb buds. J Biol Chem 279: 8219-8229.

Ostrovsky O, Berman B, Gallagher J, MulLOY B, Fernig DG, Delehedde M AND RoN D. 2002. Differential effects of heparin saccharides on the formation of specific fibroblast growth factor (FGF) and FGF receptor complexes. J Biol Chem 277: 2444-2453.

Pavão MSG, Mourão PAS, Mulloy B AND TolLEFSEN DM. 1995. A unique dermatan sulfate-like glycosaminoglycan from ascidian: Its structure and the effect of its unusual sulfation pattern on anticoagulant activity. Blood 86: 3523.
Pavão MSG, Aiello KRM, Werneck CC, Silva LCF, Valente AP, Mulloy B, Colwell ns, TOLlEFsEn DM AND Mourão PAS. 1998. Highly sulfated dermatan sulfates from ascidians - Structure versus anticoagulant activity of these glycosaminoglycans. J Biol Chem 273: 27848-27857.

PELLEGRINI L. 2001. Role of heparan sulfate in fibroblast growth factor signalling: a structural view. Curr Opin Struct Biol 11: 629-634.

Pellegrini L, Burke DF, von Delft F, Mulloy B AND BLundell TL. 2000. Crystal structure of fibroblast growth factor receptor ectodomain bound to ligand and heparin. Nature 407: 1029-1034.

Pereira MS, Mulloy B And Mourão PA. 1999. Structure and anticoagulant activity of sulfated fucans. Comparison between the regular, repetitive, and linear fucans from echinoderms with the more heterogeneous and branched polymers from brown algae. J Biol Chem 274: 7656-7667.

Perlin AS, Mackie DM AND Dietrich CP. 1971. Evidence for a (1 leads to 4)-linked 4- $O$-(-L-idopyranosyluronic acid 2-sulfate)-(2-deoxy-2-sulfoaminoD-glucopyranosyl 6-sulfate) sequence in heparin. Long-range $\mathrm{H}-\mathrm{H}$ coupling in 4-deoxy-hex-4-enopyranosides. Carbohydr Res 18: 185-194.

Petitou M, Casu B And Lindahl U. 2003. 19761983, a critical period in the history of heparin: the discovery of the antithrombin binding site. Biochimie 85: 83-89.

Pye DA, Vives RR, Hyde P ANd Gallagher JT. 2000. Regulation of FGF-1 mitogenic activity by heparan sulfate oligosaccharides is dependent on specific structural features: differential requirements for the modulation of FGF-1 and FGF-2. Glycobiology 10: 1183-1192.

Raman R, Venkataraman G, ERnst S, SAsiseKHARAN V AND SASISEKHARAN R. 2003. Structural specificity of heparin binding in the fibroblast growth factor family of proteins. Proc Natl Acad Sci USA 100: 2357-2362.

Ribeiro AC, VieIRA RP, Mourão PA AND MUlloy B. 1994. A sulfated alpha-L-fucan from sea cucumber. Carbohydr Res 255: 225-240.

RICKARD SM, MUMMERY RS, MUlloy B AND RIDER CC. 2003. The binding of human glial cell 
line-derived neurotrophic factor to heparin and heparan sulfate: importance of 2-O-sulfate groups and effect on its interaction with its receptor, GFRalpha1. Glycobiology 13: 419-426.

Sanderson RD, Yang Y, Suva LJ And Kelly T. 2004. Heparan sulfate proteoglycans and heparanase-partners in osteolytic tumor growth and metastasis. Matrix Biol 23: 341-352.

Schlessinger J, Plotnikov AN, Ibrahimi OA, Eliseenkova AV, YeH BK, YAYON A, LINHARDT RJ AND MoHAmmadi M. 2000. Crystal structure of a ternary FGF-FGFR-heparin complex reveals a dual role for heparin in FGFR binding and dimerization. Mol Cell 6: 743-750.

Shukla D, LiU J, Blaiklock P, Shworak NW, Bai X, Esko JD, Cohen GH, Eisenberg RJ, Rosenberg RD AND Spear PG. 1999. A novel role for 3- $O$-sulfated heparan sulfate in herpes simplex virus 1 entry. Cell 99: 13-22.

StRINGer SE AND Gallagher JT. 1997. Specific binding of the chemokine platelet factor 4 to heparan sulfate. J Biol Chem 272: 20508-20514.

Stringer SE, Forster MJ, Mulloy B, Bishop CR, Graham GJ and Gallagher JT. 2002. Characterization of the binding site on heparan sulfate for macrophage inflammatory protein 1alpha. Blood 100: 1543-1550.

STRINGER SE, Nelson MS AND GUPTA P. 2003. Identification of an MIP-1alpha -binding heparan sulfate oligosaccharide that supports long-term in vitro maintenance of human LTC-ICs. Blood 101: 22432245.
Sugahara K, Mikami T, Uyama T, Mizuguchi S, Nomura K and Kitagawa H. 2003. Recent advances in the structural biology of chondroitin sulfate and dermatan sulfate. Curr Opin Struct Biol 13: 612-620.

Venkataraman G, RAMAN R, SASisekharan V AND SASISEKHARAN R. 1999. Molecular characteristics of fibroblast growth factor-fibroblast growth factor receptor-heparin-like glycosaminoglycan complex. Proc Natl Acad Sci USA 96: 3658-3663.

Vilela-Silva ACES, Alves AP, Valente AP, VACQUIER VD AND MOURÃo PAS. 1999. Structure of the sulfated alpha-1-fucan from the egg jelly coat of the sea urchin Strongylocentrotus franciscanus: patterns of preferential 2- $O$ and 4- $O$-sulfation determine sperm cell recognition. Glycobiology 9: 927-933.

Vilela-Silva ACES, Castro mo, Valente AP, Biermann CH AND Mourão PAS. 2002. Sulfated fucans from the egg jellies of the closely related sea urchins Strongylocentrotus droebachiensis and Strongylocentrotus pallidus ensure species-specific fertilization. J Biol Chem 277: 379-387.

Yue X, Schultheiss TM, McKenzie EA And ROSENBERG RD. 2004. Role of heparan sulfate in dextral heart looping in chick. Glycobiology 14: 745-755. 